\title{
IMPROVEMENT EARLY COUNTING ABILITY WITH FUN COOKING ACTIVITIES
}

\author{
Duana Fera Risina ${ }^{1}$ \\ fera_risina@trilogi.ac.id ${ }^{1}$ \\ Universitas Trilogi ${ }^{1}$
}

\begin{abstract}
The objectives of the study is to know the process of fun cooking activities and increase early counting in children with learning math fun cooking activities. Fun cooking is a process of making food and drink until finally produce a product that can be eaten and done with fun. Through cooking the child will learn about language skills, mathematical concepts, skills in the process of science, experimental skills, coordination of physical skills, social skills, food and nutritional concepts. Observations made in five Kindergarten Group B in Kecamatan Selo, Boyolali found that teachers teach counting children still the old way, teachers use activity sheets in learning to count and do not use instructional media. Fun cooking activities using action research design (action research) model of Kemmis and Taggart, covering the planning, action, observation and reflection. Data analysis using quantitative and qualitative analysis (mixed methods). Quantitative data were analyzed using descriptive analysis (frequency tables, mean, percentage, standard deviation) while the qualitative data were analyzed by step 1) data reduction, (2) data display, and (3) verification of data.
\end{abstract}

Keywords: early counting ability, fun cooking activity, action research classroom

\section{INTRODUCTION}

At the age of 3-6 years the brain develops and changes rapidly, and it is at this time that the role of the teacher is enormous to create an appropriate learning environment for the child's development. Learning is a complex process, a process that involves behavioral change through experience and practice. The most important thing in the learning process is the concentration of learning. Children will easily capture the material activities if they feel comfortable and can concentrate in learning. This is related to the child's efforts to focus attention on an object so that it can understand and understand the object being noticed. If the child cant concentrate his attention will easily move from one object to another object thus the child is less able to understand a whole object.

Olivia (2010:106) states that the expectation that is always required by the teacher is how the subject matter delivered can be mastered the child completely. Concentration is the focus of attention and full awareness to the subject matter being studied. Put aside all the 
things that have nothing to do with the activity. All children's activities require concentration, with the concentration of children able to do the work faster and get better results. Due to lack of concentration of work results usually cant be maximized and completed in a long time.

In improving the concentration of numeracy learning, teachers need to design an activity that can help improve the concentration of learning in children as well as explore the objects in the surroundings of a fun and interesting that fits the interests, talents, and needs of children. One of the fun and meaningful activities that can increase the concentration of learning to count in children is through fun cooking activities. Fun cooking activity is a simple cooking activity where children participate actively in the process of making food. Children are directly involved in mixing ingredients, making dough, printing dough, and others. Children are taught to come into direct contact with stoves, hot oil and hot pots and others. Dodge, Colker and Heroman (2002: 443) cooking can be defined as "a natural laboratory for helping children to develop and learn". According to him cooking can be likened to a laboratory that can help children to grow and learn. Cooking helps introduce children to concrete objects such as plates, bowls, fryers and other cooking utensils.

Coughlin (2002: 209) Fun cooking is an activity that develops food processing skills using real materials and tools, activities in fun cooking can support all aspects. The development of the child, such as language, cognitive, fine motor, emotional social and independence. Cooking is also an activity that keeps the child active and has a purpose. Food for everyone is very important for life. Jackman (2009: 263) reveals that, food a basic human needs and so often provides great pleasure, nutrition education and cooking experiences should be an integral part of the curriculum. Can be interpreted that food is a basic human need and often provide great pleasure, nutrition education and cooking experience should be an integral part of the curriculum. Food is the closest thing to children because food is the basic necessity for life. Therefore, providing experience on eating is a natural part of a learning program and that includes cooking and education activities on nutrition can improve various aspects of child development.

Fun cooking activities designed in this study are expected to increase the concentration of numeracy learning in children group B . Researchers observed that children of Group B1 in PAUD IT Auladuna still lack the concentration when the teacher explained the activity material. This is visible when the teacher explains that the children are still busy playing alone, talking to their friends and running around in the classroom. This is a problem that must be addressed. Lack of concentration results in failure to receive lessons. 


\section{RESEARCH OBJECTIVES}

1. How is the process of implementing the fun cooking activities to improve the concentration of learning counting in children group B1 PAUD IT Auladuna?

2. Do fun cooking activities can improve the concentration of numeracy learning in children group B1 PAUD IT Auladuna?

\section{METHODS}

This research uses action research method (action reseach). This action research is conducted in the spiral form of each cycle through systematic steps that actively include study participants using the Kemmis and Taggart model. Kemmis and Taggart (1990: 4) This model includes four stages, namely (1) planning, (2) action, (3) observation, and (4) reflection.

Procedure/design of action research Kemmis and Taggart:

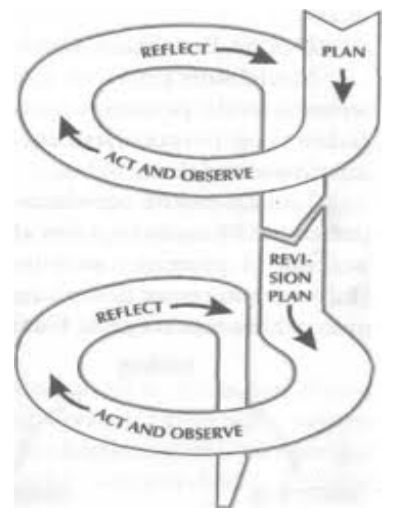

Research used in this research is action research or action research using mixed research method that is qualitative and quantitative method. Qualitative method aims to examine the learning process to increase the concentration of learning with fun cooking activities. While the quantitative method aims to examine the results of learning concentration performance with fun cooking activities.

The overall achievement targets increase the concentration of learning counting after doing fun cooking activity is when it has reached $80 \%$. This is seen based on the minimum completeness of the school (PAUD IT Auladuna) by $80 \%$. That is, action research is said to succeed if the child has increased the score of concentration of learning achievement count individual reaches at least $71 \%$ and classical learning concentration score counting (class) reaches $80 \%$. If the percentage obtained is less than $71 \%$ for the calculation of individual's learning concentration score and $80 \%$ of the concentration score of classical learning, then the research will be continued in the next cycle that is cycle II. 


\section{Action Research Procedures}

In the research procedure this action will be, pre observation, planning, action, observation and reflection:

\section{a. Pre observation}

The activities undertaken at this pre observation are: 1) determining the place of study and the problem studied, 2) collect information about the learning with the activities of fun cooking and about the concentration of learning to counting.

b. Planning

After the pre observation is done, then the next step is to plan the activities to be implemented are: 1) determine the target of competence to be achieved. 2) designing the fun cooking activities used for each action or meeting at each cycle; 3) determining the activity steps for each meeting/action; 4) setting the location of activities and preparing the tools, materials, media used.

c. Action

Implementation of the action in eight times action (fun cooking activity) in cycle I. The result and level of success of child will be know at cycle I. If result and level of success have not reached the expected success then will be done in cycle of cycle II.

d. Observation

Observations were made during the execution of action or fun cooking activities with observation guidelines that included indicators designed based on the focus of the study: the concentration of numeracy learning to be improved which included: at the time of observation, in addition to using observation sheets, and interview guides the researchers also used a tool in the form of cameras And handycam to be able to record or document the process of action activity is how the child doing fun cooking activities.

e. Reflection

Reflection is done by analyzing the results of actions performed to the child, whether the action is done there is a shortage, increase or even a decrease in the concentration of learning to count children.

\section{Technique collect data}

\section{a. Validation}

To test the level of validity in this study used:

$$
\begin{array}{cc}
r_{x y}=\frac{N \sum X Y-\left(\sum X\right)\left(\sum Y\right)}{\sqrt{\left(N \sum X^{2}-\left(\sum X^{2}\right)\left(N \sum Y^{2}-\left(\sum Y\right)^{2}\right)\right.}} \\
\mathrm{r}_{\mathrm{xy}} & : \text { correlation coefficient product moment } \\
\mathrm{n} & : \text { The number of respondents } \\
\mathrm{x} & : \text { Number of item scores }
\end{array}
$$




$\begin{array}{ll}\mathrm{y} & : \text { Total score } \\ \sum \mathrm{x} & : \text { Number of item scores } \\ \sum \mathrm{y} & : \text { Total number of total item scores } \\ \sum \mathrm{xy} & : \text { Number of multiplication between score } \mathrm{x} \text { and score } \mathrm{y}\end{array}$

\section{b. Reliability}

Popham said "the degree of which test score are free from error measurement". To know the reliability of research instruments used Cronbach Alpha:

$$
r 11=\left(\frac{k}{k-1}\right)\left(1-\frac{\sum S_{i}}{S_{t}}\right)
$$

$$
\begin{array}{ll}
\mathrm{r} 11 & : \text { Value of reliability } \\
\sum \mathrm{S}_{\mathrm{i}} & : \text { Number of variants of score items } \\
\mathrm{S}_{\mathrm{t}} & : \text { total variant } \\
\mathrm{K} & : \text { total items }
\end{array}
$$

\section{Data Analysis Technique}

Data analysis is divided into two, is the analysis of qualitative and quantitative data. Qualitative data obtained from observations, interviews, documentation and reflection results are collected and sorted by type, then analyzed inductively, with data reduction, data display and data verification. While the quantitative data from the assessment of the development of the concentration of comparative learning is processed statistically to test the hypothesis of action, that is by using the study of the proportion of values.

\section{RESULT}

Observation of the results of actions undertaken during the implementation is necessary in conducting data analysis in quantitative and qualitative terms. Observations were made using: observation instruments. The types of instruments used are field notes, documentation and interviews. Increased concentration of learning counting in children group B1 PAUD IT Auladuna Kota Bengkulu seen in the following graph: 


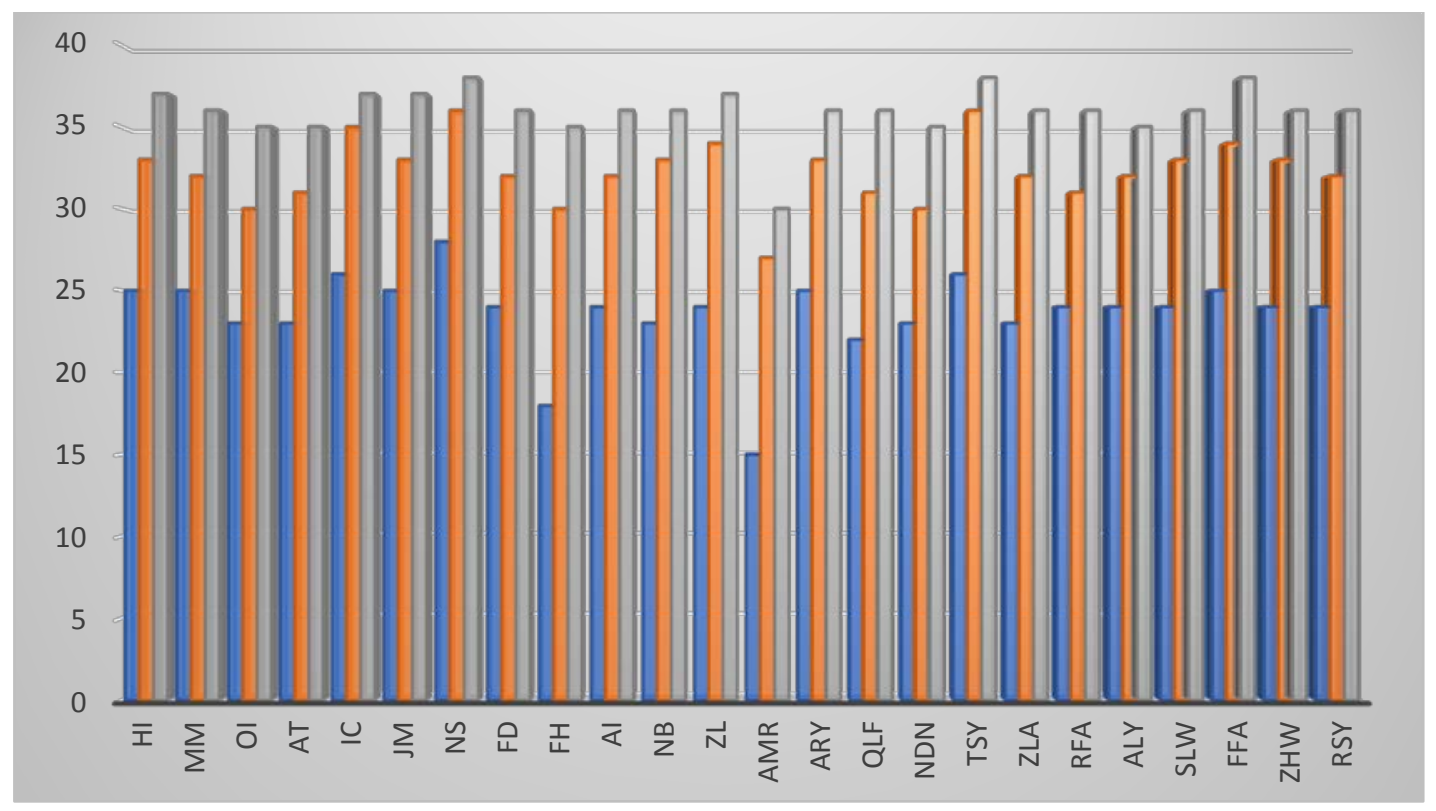

Picture 1. Graph of Comparison of Pre-Action Score Result, Cycle I and Cycle II Concentrations of Learning Calculate with Fun Cooking Activities

: Pre-action

: Cyle I

: Cyle II

From the graph above can be concluded the concentration of learning counting children group B1 PAUD IT Auladuna Bengkulu City has increased significantly and has reached the number that has been targeted of the pre-action with the average ability of children to learn to count the concentration of $59 \%$ had an increase in ability in cycle I by $22 \%$ with an average of $81 \%$. Furthermore, from cycle I to cycle II increased ability reaches $90 \%$, has increased by $9 \%$. This shows the effectiveness of the use of fun cooking activities as an activity to improve the concentration of numeracy learning.
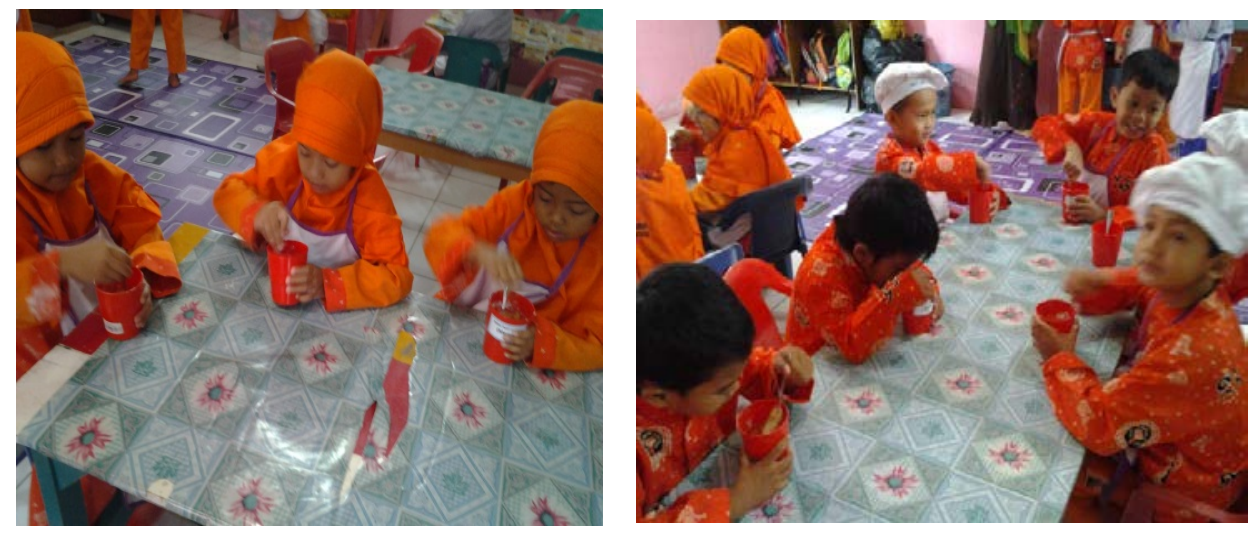

Picture 2: The child is stirring the cake of the waffle cake is funny and the children are told to count 
How many blows do the children do until the dough fused together
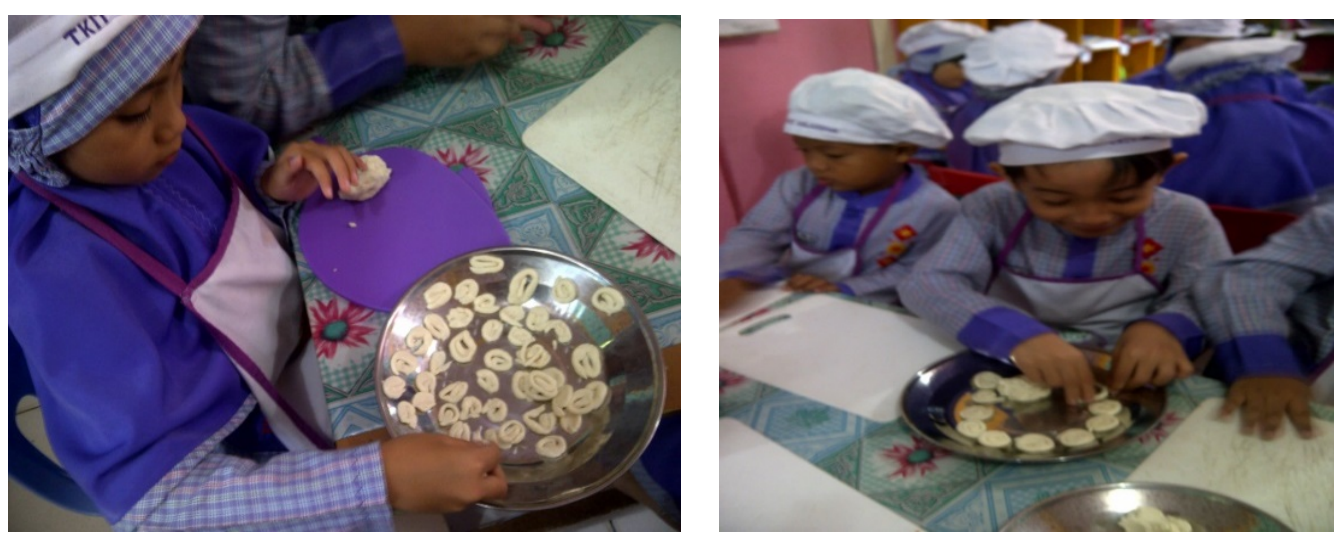

Picture 3: The child is told to count the number of delicious chips

\section{CONCLUSION}

1. The result of the overall percentage of individual values in the pre-action, cycle I and cycle has reached the total score of $80 \%$. While the average class has reached a total score of $90 \%$.

2. Fun cooking able to increase the concentration of children's learning can be seen from the improvement of development achievement concentration in counting count at 59\%, cycle I $81 \%$ and $90 \%$ in cycle II.

3. There is a significant increase of pre-action, cycle I and cycle II in every aspect of learning concentration to calculate the aspects of attention, focus, recognize numbers 120, number 1-20, count the number of objects 1-20 in group B1 PAUD IT Auladuna City of Bengkulu.

4. Teachers carry out learning concentration of arithmetic learning with fun cooking activities by: (1) clear, simple and easy working procedures by children, (2) children can practice directly, (3) managing varied learning environment. 


\section{REFERENCES}

Arikunto, Suharsimi. Prosedur Penelitian Suatu Pendekatan Praktik. Jakarta:Rineka Cipta. 2010.

Coughlin, Pamela A. Menciptakan Kelas Berpusat Pada Anak Washington DC: Children’s Respurces International, Inc. 2002.

Dodge, Diane Trister and Laura J. Colker. The Creative Curriculum For Early Childhood Third Edition. Washington DC:Teaching Strategies, Inc. 2001.

Futriana, Merlita. Validitas dan reliabilitas, (2009), (http://merlitafutriana0.blogspot.com/p/validitas-dan-reliabilitas.html) diakses 25 November 2013, 19:09 wib

Jackman, Hilda L. Early Education Curriculum: A Child's Connection to the world fith edition. USA: Wadsworth Cengage learning. 2009.

Matthew B. Milles A Huberman. Analisis Data Kualitatif, Buku Sumber Tentang Metodemetode baru (Penerjemah: Tjejep Rohensi Rohidi, Pendamping Mulyanto). Jakarta:Universitas Indonesia. 1992.

Olivia, Femi. Mendampingi Anak Belajar. Jakarta: Elex Media Komputindo.

Stephen Kemmis dan Robbin Mc. Taggart, The Action Research Planner $3^{\text {ed }}$. Victoria: Deakin University. 1988.

Trister Dodge, J. Colker and Heroman. The Creative Curriculum for Preschool $4^{\text {ed }}$. USA:Teaching Strategies, Inc. 2002. 